\title{
The Effect of Automation on Stock Market Price Volatility: A Case of Nairobi Securities Exchange
}

\author{
Jonathan Ang'ani Omuchesi ${ }^{1}$ Mary Bosire ${ }^{2}$ \\ ${ }^{I}$ Department of Accounting \& Finance,School of Business \& Economics, Mount Kenya University \\ P.O BOX 342-01000, THIKA-KENYA \\ ${ }^{2}$ Department of Accounting, Finance and Management Science,Faculty of Commerce, Egerton University \\ Nakuru Town Campus College P.O BOX 13357-20100, NAKURU-KENYA
}

\begin{abstract}
This study investigated the effect of the automation on stock market price volatility of the Nairobi Security Exchange (NSE). Two study periods were considered, pre-automation (January 2002 to June 2006) and post-automation periods (July 2008 to December 2012). This study provides empirical analysisof price volatility before and after automation at NSE. The study adopted a longitudinal research design and considered data on monthly NSE 20 Share Index and the average share closing prices on 37 NSE listed firms from January 2002 to December 2012. Secondary data was used in this analysis. Descriptive statistics were used for analysis together with a chi-square test and t-test was used to test the significance. The results indicate that the introduction of the ATS had no statistically significant effect on price volatility at the NSE.
\end{abstract}

Key words: Nairobi security exchange, NSE share index, market automation, market volatility

\section{Introduction}

There has been an increase in securities/stock market automation in Sub-Saharan Africa in the last two decades [1]. Complete automation of the market microstructure has been advanced one of the Policies for building capacities of African Securities Markets and a solution to the recurrent problems in stock market performance [2]. African stock markets are known to be illiquid and characterized by thin trading [3].

Security markets/exchanges in the world individually and collectively play a critical role in the most national economies. The main aim of a security exchange/market is to provide facilities for trade of company stocks and other financial instruments. Security exchanges have always been found in central locations for ease record of transactions. The role played by stock exchanges has remarkably transformed over the last couple of decades due to the increasing and effective role information and communication technology platforms play. Emerging markets improved their microstructures by adopting electronic trading in order to take advantage of existing technology such as Tunisia in 1996 and Jordan in 2000 [4]. Introduction of fully automated electronic trading systems, is one of the of six capital market-specific and related reforms among them stock market liberalization, enforcement of insider trading laws, privatization programs, structural pension reform, and institutional reform [5]. Security exchange automation started in the early 1970s and the transaction of securities became electronically traded through the support of information and communication technology [6].

The Nairobi Security Exchange (NSE) automated its operations through the use of an electronic trading system (the Nairobi Security Exchange Automated Trading System (NSEATS)) in 2006 prior to installation of the CDS in 2004 [7].

Automation of the trading system usually either precedes or is preceded by the adoption of a Central Depository System (CDS) [8]. Capital markets automation does not only benefit one of the players of the financial trading game, but also all the players in the sector gain from such technological breakthrough. After the automation, investors were not entitled to go and deal directly with stock exchanges; they did not have to go to a stock broker's office or deal with the hassles of calling him/her on the phone. Initially, investors had to compete for the broker's time through regular and continuous access. The application of information technology allowed the investor to reach the information he/she requires any time anywhere.

African stock markets low turnover performance and specifically Kenya has been partly attributable to the existence of manual systems. Automation has been touted as one of the policies on how to promote the development of African stock markets. Automation is expected to reduce the costs and inefficiencies associated with manual systems increases trading activity, improving market transparency and liquidity in the stock markets by speeding up operations [2].

The study assumes that the stock exchanges in Africa face the same challenges. Policy options have been discussedfor promoting the development of the stock markets in Africa [8]. To address the challenges of stock exchanges in Africa, they recommended robust electronic trading systems and central depository systems as being very crucial. The performance Stock markets are influenced by a number of factors notably the activities of governments and the general performance of the economy. Evidence shows that there is a direct 
correlation between the level of development of a nation's capital market and her overall social and economic development [9]. There is therefore, the need for a fast growing capital market, through technological innovation so as to facilitate the speedy growth and development of an economy.

The Stock Exchange of Mauritius (SEM) [10] identified the operational advantages derivable from automation and the application of the automated trading system (ATS) as; electronic matching of orders, internet trading facilities, enhancing internationalization of the stock market' multiple prices for an order, quick order execution prices and volume levels available in real time. Automation also improved market data or information, online report of prices, higher volume of trade and index, online corporate reporting, transparency of dealings and fairness in establishing order priority. The implementation of the ATS at the NSE was a key to achieving enhanced operational efficiency, transparency, reduced cost of doing business, and enhanced market integrity and investor confidence [11]. Conceptually, an automated stock market will ensure automatic monitor and a user friendly stock market. All this operational advantages of automation were to translate into improved market performance measurable in terms of market liquidity, volatility, size and efficiency.

\subsection{Automation Trends in Africa}

Automation of stock exchanges is on the increase in Africa. Since the automation of the Johannesburg stock exchange in mid 1990s and movement of the Egyptian Stock Exchange to an automated order-driven system in 1992 there have been continued efforts towards automation. The Stock exchanges in Sub-Saharan African stock exchanges have gradually adapted to electronic systems, but many of them still use manual trading systems as well as manual clearing and settlement systems. The most recent stock exchange to automate its trading system is the Botswana Stock Exchange in August 2012 with Uganda, Rwanda and Zimbabwe being in advanced stages of implementing the same [12]. See table 1

\section{Automation And Stock Market Price Volatility}

Advocates of automation suggested that execution of trades was faster and less costly under computerized trading systems. Traders have access to broader information including bid and ask prices, trades sizes and volume, at lower costs, due to the existence of a limit order book than under systems that restrict access to information about standing orders above and below the market. That would attract more investors and improve volume and liquidity and generate better price discovery. However, critics of automation argue that electronic trading could lead to less efficient prices since judgmental aspects of trade execution are lost with automation, which could be particularly important in times of fast market movements.

Volatility is likely to increase when automation speeds up the dissemination of prices especially when information is hitting the market [13]. In their study they find out reduced autocorrelations of returns, which leads them to conclude that market efficiency improves after automation at the Singapore Stock Exchange. Several studies also examined the financial effects of automation on stock market liquidity and volatility. there is documentation document that stock prices increase and liquidity improves, and cost of equity capital falls all around the world when exchanges increase transparency through computerized trading [14], [15], and [6].

There is evidence that the shift to electronic trading system increased volatility, and had no significant effect on market's efficiency [16]. A study on the Amman Stock Exchange (ASE) indicated areduction in volatility after the adoption of electronic trading and improved liquidity level [17]. However, automation of the Tunisian Stock Exchange (TSE) resulted in no significant effect on market volatility [4].

Examining the effect of automation on volatility of Toronto stock exchange [18]finds on average, automation had a significantimpact on the volatility and hence on the pricing of securities on the exchange. The evidence indicated significant changes in the structure of volatility and the risk-return relationship. The results were consistent with the interpretation that there had been an increase in the quantity of information flowing into the market post-automation.

Several studies have also focused on the effect of automation with respect to whether or not trading floor is present. Empirically, there is mixed evidence.

In comparing the NYSE (which has a trading floor) with Euronext Paris (fully screen based) for a sample of similar stocks [19] finds that spreads are lower on a floor based exchange than on an electronic exchange. An investigation of 120 stock exchanges worldwide found that a change from floor to electronic trading had a number of long run beneficial effects. He found that the equity premium is reduced significantly after the switch to electronic trading and that the cost of capital of listed firms also declined and monthly trading turnover increased and it this lowered stock market liquidity [6]. However, a study done [20] using data provided by the London Stock Exchange (LSE) and found that HFT improved liquidity and was unlikely to have increased volatility.A study conductedon micro-structure theory of the African capital markets in 1999 and discovered that with institutional changes market efficiency improved in NSE (Nigerian Stock Exchange), NSE (Nairobi stock exchange), JSE (Johannesburg stock exchange)and market liquidity also improved, while volatility reduced[21]. 
A comparison of liquidity and price formation processes in several trading systems with different degrees of transparency [22]. Transparency is the possibility to observe the size and the direction of the order flow. They suggest that greater transparency in the trading process improves market liquidity by reducing opportunities for taking advantage of less informed participants. Then, spread, volatility and pricing error are likely to decrease. Nevertheless, in terms of pre-trade reporting, too much transparency may be detrimental [23]. An efficient price discovery process is traditionally associated with lower fundamental volatility, which promotes stock market effectiveness in allocating resources. High volatility can distort resource allocation by making investors more reluctant to hold stocks. Risk-averse investors will demand a high risk premium, which increases the cost of capital and reduces market liquidity [24].

An examination on the impact of microstructure change on market efficiency at the Nairobi Securities Exchange, it is found out that introduction of automation at NSE has led to improved market efficiency. The results indicated that mean market returns in the post automation period were higher and more volatile than those in the pre automation period. She advances that the higher market returns could be attributed to improved price discovery process, while the higher volatility may be due to changes in market microstructure through the trading system[25].

The enthusiasm about stock markets performance in Africa has been talked about as much has been the solutions to the inherent problems. These studies indicate a mix in the behavior of market volatility following a shift to automated trading which indicates that automation is not a guarantee for positive improvement in market volatility.

Stock market liberalization, privatization programs via the securities markets and institutional reforms can potentially contribute to stock market performance [5]. In Kenya the implementation dates of the above variables were in the 1990s [26]. There is evidence that the Kenyan market had an upsurge in activity since 1993 due to economicreform, privatization, and relaxation of restrictions on foreign investors and of exchangecontrols [27]. More recently however, implementation of the economic reform programme has beeninconsistent and political problems remain, leading to market volatility, especially in dollar terms. To control for the intervening variable: privatization, the study will only consider data on any equity security listed by $1^{\text {st }}$ January 2002 . Since the other two variables were implemented way earlier before the study, its effect will have been captured in the before automation influencing factors.

\section{Data Type And Collection}

The study adopted a longitudinal research design. The target population comprised of all listed companies at the NSE and only included those firms listed at the NSE by 1st January 2002. Only firms with data spanning the study period were considered. Therefore only 37 firms were considered, see appendix I.

a data capture sheet was used to collect secondary data on monthly closing NSE 20 share index values and monthly closing stock prices at NSE. The data included monthly returns and closing prices from January 2002 to June 2006 (pre-automation period) and July 2008 to December 2012 (post-automation period). The data was considered reliable as NSE is mandated to collect and aggregate the data.

To differentiate between the performance in the pre and post automation periods, estimations were done for the pre-automation and post automation periods. Since the automation process took some time before it was finally implemented as a result of some institutional and implementation challenges at the exchange, the periods of implementation was excluded. Therefore the pre-automation period was taken as the 54 months from 1st January 2002 to 30th June 2006, while the post automation period was taken as the 54 months from 31 st July 2006 to 31st December, 2012. Thus, the period starting from 1st July 2006 to 30th June 2008 was excluded from the analysis as during this period the NSE was operating under both manual listing and automated listing and coping with the challenges of initial implementation.

\subsection{Testing for Stock Market Price Volatility}

The volatility of securities was defined by fluctuations of stock prices, which was estimated by the variance or the standard deviation of stock returns. Price volatility was measured using one month returns as defined by the natural logarithm of price relative;

$$
\mathrm{R}_{\mathrm{t}}=\operatorname{In}\left(\frac{\mathrm{P}_{\mathrm{t}}}{\mathrm{P}_{\mathrm{t}-1}}\right)
$$

Where $\mathrm{P}_{\mathrm{t}}$ denoted the prices observed at one month interval. Transaction prices on/nearest the last day of the month were identified to calculate intra-month returns. For each stock, the one month returns were averaged across the 108 trading months to compute the standard deviation denoted by $\sigma$ [28 and 29]

The standard deviation of return (r) from a sample of $n$ observations was the square root of the average squared deviation of returns from the average in the sample.

Thus 
Where,

$$
\sigma=\left[\frac{1}{n} \sum_{t=1}^{n}\left(r_{t}-m\right)^{2}\right]^{1 / 2}
$$

$\sigma=$ standard deviation

$\mathrm{n}=$ number of continuous returns

$r_{t}=$ continuous returns

$\mathrm{m}=$ average returns

$r_{t}=\operatorname{In}\left(\frac{P_{t}}{P_{t-1}}\right) a n d r_{t}$ is the rate of return for the period $t$, and $P_{t-1}$ and $P_{t}$ are the prices for two successive periods $(\mathrm{t}-1)$ and $\mathrm{t}$,

$$
\mathrm{m}=\left\{\frac{1}{\mathrm{n}} \sum_{\mathrm{t}=1}^{\mathrm{n}} \mathrm{r}_{\mathrm{t}}\right\} / \mathrm{n}
$$

For this study monthly volatility measures were used which were computed as the 12 month rolling standard deviation estimate that was based on market returns.

Volatility was calculated as the standard deviation of the natural $\log$ of returns in indices for the respective period. This measure has also been applied in measuring volatility in the Indian stock Indian stock market. An increase in standard deviation would denote an increase in volatility [28].

Similarly, for each stock, the one month returns were averaged across the 108 trading months to compute the variance denoted by $\operatorname{Var}\left(\mathrm{R}_{\mathrm{t}}\right)$. The volatility of securities as defined by fluctuations of stock prices was estimated by the variance or the standard deviation of stock returns. If the change in trading mechanism had no effect on stock volatility, the variance would be the same for the two return series (before and after the transfer).

Chi-square and t-test $\mathrm{s}$ were used to establish the significance

Cross-sectional averages of one month return variances were calculated across the whole sample as well as for two subgroups. The same approach has also been used to measure price volatility on Taiwan stock exchange [29].

The Chi-square model is shown below:-

Mean: Ungrouped data $\overline{\mathrm{x}}=\sum \mathrm{x} / \mathrm{N}$

Where:

$$
\text { Grouped data } \overline{\mathrm{x}}=\sum \mathrm{f}(\mathrm{x}) / \sum \mathrm{f}
$$

$\overline{\mathbf{x}}=$ Mean

$\sum \mathrm{f}=$ Summation of frequency

$\mathrm{N}=$ Number of scores

$\sum \mathrm{f}(\mathrm{x})=$ Summation of each value of $\mathrm{x}$ multiplied by its corresponding frequency (f)

Chi-square $x^{2}=\sum\left(f_{o}-f_{e}\right)^{2} / f_{e}$

Where:

$\mathrm{x}^{2}=$ Chi - square

$\mathrm{f}_{\mathrm{o}}=$ an observed frequency

$\mathrm{f}_{\mathrm{e}}=$ an expected frequency

$\Sigma=$ Summation

A standard t-test for difference of means was also conducted on the data to establish the significance of the differences between the measures of stock market performance before and after automation. For equal sized samples the t-value was given by:

$$
\mathrm{t}=\frac{\mathrm{m}_{1}-\mathrm{m}_{2}}{\sqrt{\left[\left(\mathrm{V}_{1}-\mathrm{V}_{2}\right) / \mathrm{n}\right]}}
$$

Where $m_{i}$ and $V_{i}$ are respectively the mean and the variance for the $i^{\text {th }}$ period and $n$ is the sample size. The degrees of freedom for the test will be given by $2 n-2$.

\subsection{Introduction}

\section{Results And Discussions}

The analysis of the data set first sought to examine relevant summary statistics, and a variety of graphical displays using standard summary measures of location and spread of the distribution of the variables such as minimum, maximum, mean, standard deviation, skewness, and kurtosis. The second part of the chapter uses inferential statistics to examine the effects of adaptation to electronic or automated trading by the Nairobi Securities Exchange (NSE) on the five measures of stock market performance. The final part of the chapter discusses the results of the analysis within the context on the existing body of theory and empirical findings. 


\subsection{Descriptive Statistics}

Volatility referred to the variability in market returns as measured by standard deviation as well as variance of the stock prices. Descriptive statistics indicated a downward trend in the amount of standard deviation with before Mean=.153, after Mean=.126. Similarly, a downward trend in the amount of variance with before Mean $=0.029$, after Mean $=0.021$. However, these are indicative descriptive statistics with statistical tests to examine if the changes were indeed significant addressed later in the chapter.

The volatility distribution is asymmetrical as the skewness coefficient is equal to zero for both pre and post-automation period for standard deviation. However, the pre-automation volatility distribution variance is asymmetrical, the post-automation distribution variance appears normal with a skewness coefficient of 3.033. However, the pre and post-automation distribution standard deviation and variance indicate a leptokurtic distribution (See Table 2).

\subsubsection{Stock Market Price Volatility Trend}

Presented in form of a time series trend line chart, the two measures used to represent volatility provided overall same picture indicating that there were mixed movements in market volatility that could not be discerned to be systemic showing a change in the market situation. Both standard deviation chart and variance chart are used. (See figures 1 and 2)

The mean standard deviation of stock returns was at one time highest (worse) under pre-automation regime and one time lowest (better) under the post-automation regime.

The mean variance of stock returns was at one time highest (worse) under pre-automation regime and one time lowest (better) under the post-automation regime.

\subsection{Effect of Automation on Market Volatility}

Volatility referred to the variability in market returns as measured by standard deviation as well as variance of the stock prices. While descriptive statistics indicated a downward trend in the amount of standard deviation (before $\mathrm{M}=.153, \mathrm{SD}=.0790$, after $\mathrm{M}=.126, \mathrm{SD}=.0750$ ), there was no significant evidence that this was actually the case at 0.05 level of significance $[t(36)=-1.689, p=0.100]$. (See Table 3 )

A crosstabulation of the changes in the market volatility as measured by the standard deviation of the returns returned a mixed change that could not systemically point toward a certain direction (See Table 4).

When subjected to a chi-square test, it was found out that there was no significant change in the volatility in the market at 0.05 level of significance $\left[\chi^{2}(2)=2.520, p=.284\right]$. Therefore, the results from chisquare test provided further evidence in support of the t-test results. (See table 5)

Variance of the market returns was also used to measure the volatility in the market. A t-test showed a slight decrease in the volatility (from $\mathrm{M}=.029, \mathrm{SD}=.041$ to $\mathrm{M}=.021, \mathrm{SD}=.028$ ). The differences were not significant at 0.05 level of significance $[\mathrm{t}(36)=-1.073, \mathrm{p}=.290]$ (See Table 6).

A crosstabulation of the changes in variance in respect to the type of the trading system indicated were consistent across all the volatility categories signaling no significant changes. (See Table 7)

A chi-square test of independence confirmed that indeed there were no significant change in the volatility of the market returns at 0.05 level of significance $[\chi 2(2)=1.333, \mathrm{p}=0.513]$ (see table 8 ).

\subsection{Discussions}

The study found that volatility of the returns series were thesame both before and after automation of the trading system. It would be expected that major episodes in the market history such as the use of automated platforms may exacerbate volatility due to increased intensity of trading activities [30]. Conversely, automation could increase the portfolio flows thereby raising liquidity resulting in reduced volatility. However, this study found no such evidence.

\subsection{Summary of the Findings}

\section{Summary And Conclusions}

The study found that volatility of the returns series were the same both before and after automation of the trading system. Whereas major economic or political episodes may affect volatility, no significant differences were found in the study to indicate that volatility was affected by the automation process. It would have been expected for volatility to either increase or decrease as the automation process were likely to signal either increased efficiency or led to increased portfolio flows.

\subsection{Conclusions}

The study concludes that automation of the Nairobi Securities Exchange did not significantly affect its stock price volatility 


\subsection{Suggestion for further research}

The study suggests that future research may be carried to confirm and assess the determinants of lower liquidity positions in the market after introduction of the automated trading system. Further research could also be conducted into the post-automation efficiency/volatility/liquidity level of the NSE by adopting different estimation techniques as well as extending the sample size and scope so as to ascertain the exact effect of the automation on exchange.

\section{References}

[1]. Senbet, L., \&Otchere, I. (2008). Beyond Banking: Developing Markets; African Stock Market.African Finance for the 21st Century High-Level Seminar Organized by the IMF Institute in Collaboration with the Joint Africa Institute. Tunisia, March 4-5.

[2]. Capital Markets Authority. (2010). A comparative analysis of the performance of African stock markets for the period 2008 to 2009:Research, Policy Analysis and Planning Department Vol. II. (June 2010)

[3]. Mlambo, C. \&Biekpe, N. (2005). Thin-trading on African stock markets: Implications on market efficiency testing. The Investment Analyst Journal 61, 29-40.

[4]. Sioud, O. \&Hmaied, D. (2003). The Effects of Automation on Liquidity, Volatility, Stock Returns and Efficiency: Evidence from the Tunisian Stock Market. Review of Middle East Economics \& Finance, Vol.1, 141-154.

[5]. de la Torre, A., \&Schmukler, S. (2006). Emerging capital markets and globalization: The Latin American experience. Stanford University Press, Palo Alto, and the World Bank, Washington, DC.

[6]. Jain, P.K. (2005). Financial market design and the equity premium: Electronic vs. floor trading, Journal of Finance 60, 6, 29552985.

[7]. Nairobi Stock Exchange. (2013). History of the Exchange. Retrieved from http://www.nse.co.ke/about-nse/history-oforganisation.html accessed on 5/03/13@2.52pm

[8]. Yartey, C. A., \&Adjasi, C. K. (2007). Stock Market Development in Sub-Saharan Africa: Critical Issues and Challenges. IMF Working Paper Series WP/07/209.

[9]. Okereke-Onyiuke, N. (2000) Workshop on "Legislation for the Capital Market in a Democratic Environment"; Organized by the Securities and Exchange Commission for Senate and House of Representatives Committee. Thursday, October 12, 2002.

[10]. The Stock Exchange of Mauritius (SEM) (2004). "Stock Exchange of Mauritius" Automated Trading System (SEMATS). Retrieved from www.semdex.com.

[11]. Capital Markets Authority (2007). Annual Report 2007, Page 10

[12]. African Capital Markets News (September 4th, 2012). Botswana Stock Exchange launches automated trading. Available at.http://www.africancapitalmarketsnews.com/1690/botswana-stock-exchange-launches-automated-trading/

[13]. Naidu, G.N. and Rozeff, M.S. (1994).Volume, volatility, liquidity and efficiency on the Singapore Stock Exchange before and a fter automation. Pacific-Basin Finance Journal 2, 23-42.

[14]. Domowitz, I., \&Steil, B. (2001). Innovation in equity trading systems: The Impact on transactions costs and cost of capital in Richard Nelson, David Victor, and Benn Steil, ed.: Technological Innovation and EconomicPerformance, (Princeton University Press).

[15]. Muscarella, C.J. \&Piwowar, M.S. (2001). Market microstructure and security values: Evidence from the Paris Bourse, Journal of Financial Markets 4, 209-229.

[16]. Maghyereh, A. (2005). Electronic Trading and Market Efficiency in an Emerging Market: The Case of the Jordanian Capital Market. Available at http://mesharpe.metapress.com/link.asp?target=contribution\&id=6TPFC9EHK9B3T81V

[17]. Al-Khouri, R. \& Al-Ghazawi, N. (2008). The effect of electronic trading on market volatility and liquidity in emerging markets: Evidence from Amman Stock Exchange. Journal of Derivatives \& Hedge Funds; Nov 2008-Feb2009, Vol. 14 Issue 3/4, 222

[18]. Assaf, A. (2005). Automation, Stock Market Volatility and Risk-Return Relationship: Evidence from "CATS". Investment Management and Financial Innovations, 3/2005

[19]. Venkataraman, K. (2001). Automated Versus Floor Trading: An Analysis of Execution Costs on the Paris and New York Exchanges.Journal of Finance 56, 1445 1485

[20]. Jarnecic, E. \& Snape, M. (2010). An analysis of trades by high frequency participants on the London Stock Exchange.http://mfs.rutgers.edu/MFC/MFC17/MS/MC10 447_Snape_Jarnecic.pdf!

[21]. Murinde, V. (2006). Capital Markets Roles and challenges. Birmingham: university of Birmingham. Retrieved from www.bham.ac.uk/staffitem.asp?section

[22]. Pagano, M. \&Roelle, A. (1996). Transparency and Liquidity: A Comparison of Auction and Dealer Markets with Informed Trading Journal of Finance, vol. 51: 579-611.

[23]. Madhavan, A., Porter, D., \& Weaver D. (2002). Should Securities Markets Be Transparent? Working paper, Baruch University.

[24]. Kim, E.H. \& V. Singal (2000). Stock market openings: Experience of emerging economies. Journal of Business, 73(1): 25-66.

[25]. Okumu, N.A. (2013). Impact of Microstructure Changes on Market Efficiency at the NSE-Unpublished MBA Dissertation, Kenyatta University.

[26]. Maehle, N., Teferra, H., \&Khachatryan, A. (2013). Exchange Rate Liberalization in Selected Sub-Saharan African Countries: Successes, Failures, and Lessons. IMF Working PaperWP/13/32.

[27]. Jefferis, K., \& Smith, G. (2005). "The changing efficiency of African stock Markets", South African Journal of Economics, Vol. $73: 1$

[28]. Goel, K., \& Gupta, R. (2011). Impact of Globalization on Stock Market Development in India: Delhi Business Review X Vol. 12, No. 1 (January - June 2011).

[29]. Chang, R., Hsu, s., Huang, N. \& Rhee, S. (1998). The effects of trading methods on volatility and liquidity: Evidence from Taiwan Stock Exchange. Journal of BusinessFinance and Accounting, 26(1/2): 137-170.

[30]. Uppal, J. (1998). Stock return volatility in an emerging market: A case of the Karachi Stock Exchange. Managerial Finance, 24(3), $34-51$ 
Appendix I: Listed Equity Firms Considered In The Study

\begin{tabular}{|c|c|c|c|}
\hline & Agricultural & & Construction \& Allied \\
\hline 1 & Eaagads Ltd Ord 1.25 AIM & 22 & Athi River Mining Ord 5.00 \\
\hline 2 & Kakuzi Ord.5.00 & 23 & Bamburi Cement Ltd Ord 5.00 \\
\hline 3 & Kapchorua Tea Co. Ltd OrdOrd 5.00 AIM & 24 & Crown Berger Ltd Ord 5.00 \\
\hline 4 & Limuru Tea Co. Ltd Ord 20.00 AIM & 25 & E.A.Cables Ltd Ord 0.50 \\
\hline 5 & Rea Vipingo Plantations Ltd Ord 5.00 & & Energy \& Petroleum \\
\hline 6 & Sasini Ltd Ord 1.00 & 26 & KenolKobil Ltd Ord 0.05 \\
\hline \multirow[t]{2}{*}{7} & Williamson Tea Kenya Ltd Ord 5.00 AIM & 27 & Kenya Power \& Lighting Co Ltd Ord 2.50 \\
\hline & Automobiles \& Accessories & 28 & Total Kenya Ltd Ord 5.00 \\
\hline 8 & Car \& General (K) Ltd Ord 5.00 & & Insurance \\
\hline \multirow[t]{2}{*}{9} & Marshalls (E.A.) Ltd Ord 5.00 & 29 & Jubilee Holdings Ltd Ord 5.00 \\
\hline & Banking & 30 & Pan Africa Insurance Holdings Ltd Ord 5.00 \\
\hline 10 & Barclays Bank Ltd Ord 0.50 & & Investment \\
\hline 11 & Diamond Trust Bank Kenya Ltd Ord 4.00 & 31 & City Trust Ltd Ord 5.00 AIM \\
\hline 12 & Housing Finance Co Ltd Ord 5.00 & & Manufacturing \& Allied \\
\hline 13 & Kenya Commercial Bank Ltd Ord 1.00 & 32 & A.Baumann\& Co Ltd Ord 5.00 AIM \\
\hline 14 & National Bank of Kenya Ltd Ord 5.00 & 33 & British American Tobacco Kenya Ltd Ord 10.00 \\
\hline 15 & NIC Bank Ltd Ord 5.00 & 34 & East African Breweries Ltd Ord 2.00 \\
\hline \multirow[t]{2}{*}{16} & Standard Chartered Bank Ltd Ord 5.00 & 35 & Kenya Orchards Ltd Ord 5.00 AIM \\
\hline & Commercial \& Services & 36 & Mumias Sugar Co. Ltd Ord 2.00 \\
\hline 17 & Express Ltd Ord 5.00 AIM & 37 & Unga Group Ltd Ord 5.00 \\
\hline 18 & Kenya Airways Ltd Ord 5.00 & & \\
\hline 19 & Nation Media Group Ord. 2.50 & & \\
\hline 20 & Standard Group Ltd Ord 5.00 & & \\
\hline 21 & TPS Eastern Africa (Serena) Ltd Ord 1.00 & & \\
\hline
\end{tabular}

Table 1: Infrastructural indicators of African Stock Exchanges

\begin{tabular}{|l|c|c|c|}
\hline \multicolumn{1}{|c|}{ COUNTRY } & CSD & TRADING SYSTEM & YEAR OF AUTOMATION \\
\hline Botswana & Electronic & Electronic & 1912 \\
\hline C/d'Ivoire & Electronic & Electronic & 1999 \\
\hline Egypt & Electronic & Electronic & 2008 \\
\hline Ghana & Electronic & Electronic & 2006 \\
\hline Kenya & Electronic & Electronic & 2001 \\
\hline Mauritius & Electronic & Electronic & 1997 \\
\hline Morocco & Manual & Electronic & 1998 \\
\hline Namibia & Manual & Electronic & 1999 \\
\hline Nigeria & Electronic & Electronic & 1996 \\
\hline S/Africa & Electronic & Electronic & 2006 \\
\hline Tanzania & Electronic & Electronic & \\
\hline Tunisia & Electronic & Electronic & \\
\hline Zambia & Electronic & Manual & \\
\hline
\end{tabular}

Source: Researchers' Compilation from Data on Stock Exchange websites \& Jain (2004)

Table 2: Description of Stock Market Price VolatilityIndicators

\begin{tabular}{|l|l|c|c|c|c|c|c|c|}
\hline & & $\mathrm{n}$ & Min & Max & Mean & Std. Deviation & Skewness & Kurtosis \\
\hline Volatility & $\begin{array}{l}\text { Pre-std } \\
\text { deviation }\end{array}$ & 37 & 0.0241 & 0.4997 & 0.15259 & 0.07905 & 2.54 & 10.011 \\
\hline & $\begin{array}{l}\text { Post-std } \\
\text { deviation }\end{array}$ & 37 & 0 & 0.374 & 0.12628 & 0.07500 & 1.478 & 3.41 \\
\hline & Pre-variance & 37 & 0.0006 & 0.2497 & 0.02936 & 0.04132 & 4.563 & 23.618 \\
\hline & Post-variance & 37 & 0 & 0.1399 & 0.02142 & 0.02837 & 3.033 & 9.97 \\
\hline
\end{tabular}




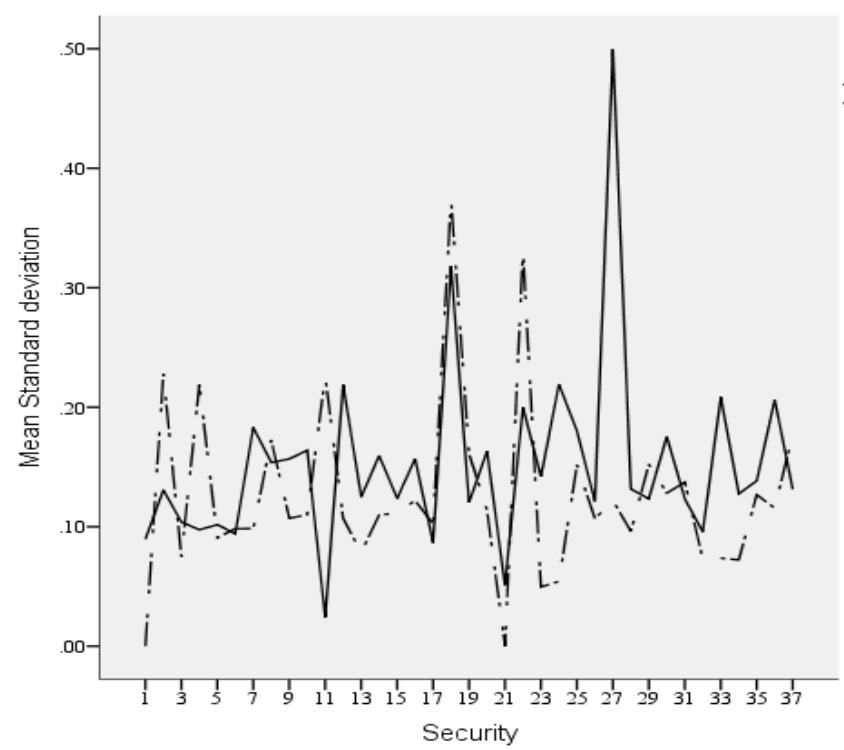

Automation

regime

- Pre-automation

Figure 1: Standard Deviation Trend

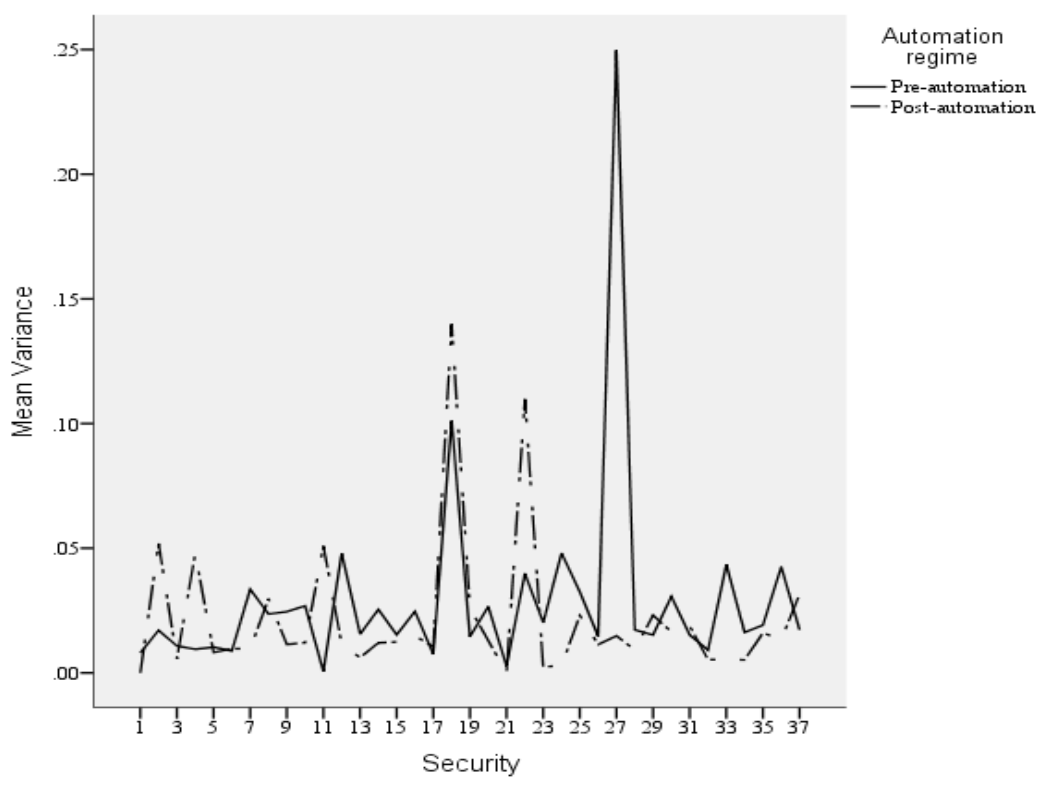

Figure 2: Variance Trend

Table 3: T-Test for Standard Deviation Differences

\begin{tabular}{|l|l|l|l|l|l|l|l|l|}
\hline \multicolumn{2}{|l|}{ Paired Samples Statistics } & & & & & & \\
\hline
\end{tabular}


Table 4: Standard Deviation and Automation Regime Crosstabulation

\begin{tabular}{|c|c|c|c|c|c|}
\hline \multicolumn{6}{|c|}{ Standard deviation (Binned) * Automation regime Crosstabulation } \\
\hline & & & \multicolumn{2}{|c|}{ Automation regime } & \multirow[t]{2}{*}{ Total } \\
\hline & & & After & Before & \\
\hline \multirow[t]{6}{*}{ Standard deviation (Binned) } & Low & Count & 7 & 13 & 20 \\
\hline & & $\%$ of Total & $9.5 \%$ & $17.6 \%$ & $27.0 \%$ \\
\hline & Average & Count & 28 & 22 & 50 \\
\hline & & $\%$ of Total & $37.8 \%$ & $29.7 \%$ & $67.6 \%$ \\
\hline & High & Count & 2 & 2 & 4 \\
\hline & & $\%$ of Total & $2.7 \%$ & $2.7 \%$ & $5.4 \%$ \\
\hline \multirow[t]{2}{*}{ Total } & & Count & 37 & 37 & 74 \\
\hline & & $\%$ of Total & $50.0 \%$ & $50.0 \%$ & $100.0 \%$ \\
\hline
\end{tabular}

Table 5: Chi-square Test for Independence between Automation Regime and Standard Deviation

\begin{tabular}{|l|l|r|r|}
\hline Chi-Square Tests & \multicolumn{1}{|c|}{ Value } & Df & Asymp. Sig. (2-sided) \\
\hline Pearson Chi-Square & $2.520 \mathrm{a}$ & 2 & .284 \\
\hline Likelihood Ratio & 2.550 & 2 & .279 \\
\hline Linear-by-Linear Association & 1.729 & 1 & .189 \\
\hline N of Valid Cases & 74 & & \\
\hline
\end{tabular}

a. 2 cells $(33.3 \%)$ have expected count less than 5 . The minimum expected count is 2.00 .

Table 6: T-test for the Difference in Variance

\begin{tabular}{|c|c|c|c|c|c|c|c|c|c|}
\hline \multicolumn{10}{|c|}{ Paired Samples Statistics } \\
\hline & & Mean & $\mathrm{N}$ & $\begin{array}{l}\text { Std. } \\
\text { Deviation }\end{array}$ & \multicolumn{2}{|c|}{ Std. Error Mean } & & & \\
\hline \multirow{2}{*}{ Pair 1} & After & .021418 & 37 & .0283700 & .0046640 & & & & \\
\hline & Before & .029364 & 37 & .0413208 & .0067931 & & & & \\
\hline \multicolumn{10}{|c|}{ Paired Samples Correlations } \\
\hline & & $\mathrm{N}$ & Correlation & Sig. & & & & & \\
\hline Pair 1 & $\begin{array}{l}\text { After \& } \\
\text { Before } \\
\end{array}$ & 37 & .207 & .220 & & & & & \\
\hline \multicolumn{10}{|c|}{ Paired Samples Test } \\
\hline & & \multicolumn{2}{|c|}{ Paired Differences } & & & & $\mathrm{t}$ & $\mathrm{df}$ & $\mathrm{p}$ \\
\hline & & Mean & Std. Deviation & $\begin{array}{l}\text { Std. Error } \\
\text { Mean }\end{array}$ & \multicolumn{5}{|c|}{ 95\% Confidence Interval of the Difference } \\
\hline & & & & & Lower & Upper & & & \\
\hline Pair 1 & $\begin{array}{l}\text { After - } \\
\text { Before }\end{array}$ & -.00795 & .0450346 & .0074036 & -.022960 & .007069 & -1.073 & 36 & .290 \\
\hline
\end{tabular}

Table 7: Crosstabulation of Variance and Automation Regime

\begin{tabular}{|c|c|c|c|c|c|}
\hline \multicolumn{6}{|c|}{ Variance (Binned) * Automation regime Crosstabulation } \\
\hline & & & \multicolumn{2}{|c|}{ Automation regime } & \multirow[t]{2}{*}{ Total } \\
\hline & & & Before & After & \\
\hline \multirow[t]{6}{*}{ Variance (Binned) } & Low & Count & 35 & 35 & 70 \\
\hline & & $\%$ of Total & $47.3 \%$ & $47.3 \%$ & $94.6 \%$ \\
\hline & Average & Count & 1 & 2 & 3 \\
\hline & & $\%$ of Total & $1.4 \%$ & $2.7 \%$ & $4.1 \%$ \\
\hline & High & Count & 1 & 0 & 1 \\
\hline & & $\%$ of Total & $1.4 \%$ & $.0 \%$ & $1.4 \%$ \\
\hline \multirow[t]{2}{*}{ Total } & & Count & 37 & 37 & 74 \\
\hline & & $\%$ of Total & $50.0 \%$ & $50.0 \%$ & $100.0 \%$ \\
\hline
\end{tabular}

Table 8: A Chi-Square Test for the Difference in Variances

\begin{tabular}{|c|c|c|c|}
\hline \multicolumn{2}{|l|}{ Chi-Square Tests } & \multirow[b]{2}{*}{ Df } & \multirow{2}{*}{ Asymp. Sig. (2-sided) } \\
\hline & Value & & \\
\hline Pearson Chi-Square & $1.333 \mathrm{a}$ & 2 & .513 \\
\hline Likelihood Ratio & 1.726 & 2 & .422 \\
\hline Linear-by-Linear Association & .148 & 1 & .700 \\
\hline $\mathrm{N}$ of Valid Cases & 74 & & \\
\hline
\end{tabular}

a. 4 cells $(66.7 \%)$ have expected count less than 5 . The minimum expected count is .50 . 